\title{
De necios a idiotas. Transformaciones discursivas del léxico de menosprecio intelectual
}

\author{
From fools to idiots. Discursive transformations of the explicit \\ lexicon of intellectual denigration
}

Juan Antonio González de Requena Farré1

Fecha de recepción: 19 de agosto de 2020

Fecha de Aceptación: 11 de octubre de 2020 


\section{Resumen}

Aunque existen valiosos ensayos y estudios en ciencias sociales sobre la estupidez humana, las diferentes formas de falta de inteligencia se conciben mejor cuando se asocian al léxico y a los discursos de menosprecio intelectual en un ámbito idiomático específico como la moderna comunidad hispanohablante. En este estudio se realiza un análisis lexicográfico de las frecuencias de los principales términos explícitos de menosprecio intelectual (necio, tonto, ignorante, estúpido, bobo, idiota, imbécil e insensato) en los corpus CORDE y CREA, entre el siglo XV y el siglo XX. Además, analizamos cualitativamente las definiciones del léxico de menosprecio intelectual en algunos diccionarios modernos, e interpretamos los discursos representativos en que ese vocabulario adquiere sentido. Como resultado, se observa un desplazamiento en los léxicos y discursos del menosprecio intelectual, que podríamos caracterizar como una psicologización o mentalización de la incapacidad intelectual, así como un tránsito del discurso moral al discurso médico-legal.

Palabras clave: estupidez, falta de inteligencia, menosprecio intelectual, léxico denigratorio.

\section{Abstract}

Although there are valuable essays and studies in the social sciences on stupidity, the different forms of lack of human intelligence are best conceived when they are associated with the lexicon and discourses of intellectual denigration in a specific idiomatic setting such as the modern Spanish-speaking community. In this study, a lexicographic analysis of the frequencies of the main explicit terms of intellectual denigration (necio, tonto, ignorante, estúpido, bobo, idiota, imbécil and insensato) is carried out in the CORDE and CREA corpus, from 15th to 20th century. Furthermore, we qualitatively analyze the definitions of the lexicon of intellectual denigration in some modern dictionaries, and we interpret the representative discourses in which that vocabulary acquires meaning. As a result, a shift in lexicons and discourses of intellectual denigration is observed, which we could characterize as a psychologization or mentalization of intellectual incapacity, as well as a transition from moral discourse to medical-legal discourse.

Keywords: stupidity, lack of intelligence, intellectual denigration, denigrating lexicon. 


\section{Introducción}

La inquietud ante la falta de inteligencia humana no es nueva. El léxico esencial para referirse peyorativamente a una capacidad intelectual insuficiente tampoco es reciente. Del latín recibimos todo un catálogo de términos con los cuales se articularon los diversos matices de un entendimiento torpe o un conocimiento insuficiente. Así, en la monumental síntesis enciclopédica del saber antiguo aportada por las Etimologías de San Isidoro de Sevilla (obra compuesta en el siglo VII), ya encontramos un léxico básico para designar diferentes problemas intelectuales: imbecillus significa la débil fragilidad e inconstancia (supuestamente, a falta de báculo) (San Isidoro de Sevilla, 2004, p. 815); ignarus o ignorante es el que ignora (presuntamente, por falta de olfato: sine naribus); inscius remite a quien carece de ciencia, e idiota sería una palabra de origen griego para significar al inexperto (p. 817); obtunsus denota al obtuso y confundido (o tundido) (p. 827); el insipiens o necio carecería de criterio o sapiencia; stultus sería el embotado que, por aturdimiento (per stuporem), no reacciona ante las injurias y afrentas; stupidus, el estúpido al pie de la letra, frecuentemente quedaría estupefacto (p. 837).

Por lo demás, desde el Renacimiento hemos forjado todo un imaginario satírico de la estupidez como reverso de la inteligencia humana. En su encomio de la estulticia (Moriae Encomium, sive Stultitiae Laus, obra originalmente publicada en 1511), Erasmo de Rotterdam nos suministró una descripción satírica de las nodrizas, séquito y comitiva de la estupidez humana, simbólicamente articulada con nombres griegos: Metea o la embriaguez y Apedia o la inexperiencia ignorante serían las guías inspiradoras de la estupidez; las acompañan la altiva Filautía o el amor propio, la lisonjera Colaquía o la adulación, la adormecida Lete o el olvido, Misoponía o la pereza cruzada de brazos, la acicalada Hedoné o la voluptuosidad, Anoia o la aturdida insensatez que nada distingue, Trifé o la molicie, así como el impetuoso festejo o Comon y, finalmente, Negreton Hipnon o la modorra profunda (Erasmo,1842, pp. 46-47).

A partir del legado satírico de Erasmo, Jean Paul Richter retrató en su Elogio de la estupidez (originalmente publicado en 1782 como Das Lob der Dummheit) los distintos aspectos, rostros y profesiones de la estupidez humana: los demasiado ricos y poderosos, que no se preocupan del pensamiento y desestiman a quienes pudieran ser menos estúpidos que ellos; el cortesano adulador y corto de entendimiento, que solo encubre imaginariamente sus limitaciones al elogiar las del poderoso; la pedantería de los intelectuales y la charlatanería de los fatuos; la falsa profundidad y el razonamiento tan débil como sectario, incomprensible y absurdamente sofisticado de los filósofos de escuela; el pedagogo pedante que solo fuerza la repetición de lecciones inútiles y enseña severamente a aprender a ser estúpido; el poeta idiota a la moda, que solo alaba a sus mecenas, y el protector que paga al idiota por elogiar la estupidez; la supuesta elevación espiritual del clérigo, a fuerza de sermonear en vano y repetir parroquialmente enredos teológicos al púlpito; profesiones como la de los juristas o los médicos, que a través de su práctica solo repiten errores y producen dictámenes descabellados (Richter, 2012, pp. 13-14 y 32-34).

En el pensamiento moderno también hubo intentos notables de sistematizar conceptualmente las formas de debilidad cognitiva o insuficiencia del alma respecto a su capacidad de conocer. En su Antropología en sentido pragmático (originalmente publicada en 1798), Kant no solo introdujo una descripción mundana de las facultades humanas de conocer: el entendimiento que subsume conceptualmente los objetos bajo reglas; el juicio o discernimiento que discrimina los límites de aplicación de los conceptos y 
reglas; el ingenio, que halla la pauta universal en lo particular y, en su grado máximo, deviene agudeza; por último, la razón, que ensancha con principios universales la concepción e intelección, obstruyendo el prejuicio. Además, el filósofo ilustrado proporcionó una serie de máximas del pensar, que sirven de guía para lograr la ilustración y autonomía intelectuales: pensar por uno mismo, imaginarse en el lugar del otro y ser consecuente al pensar de acuerdo con uno mismo (Kant, 2004, pp. 152-154). De ese repertorio de facultades, cabe inferir las formas insuficientes del alma en su capacidad de conocer: el obtuso (Stumpfe Kopf) carece de ingenio; la carencia de juicio sin ingenio caracteriza a la estupidez (Dummheit); la dificultad de aprender con el entendimiento es propia del simple (Einfältig); la tontería (Torheit) no sopesa el valor e importancia de los fines; si el tonto es ofensivo, topamos con la necedad (Narrheit); el petulante o fatuo (Laffen) es un necio pretencioso; la idiotez (Blödsinnigkeit) consiste en la plena debilidad de la mente y la máxima falta de inteligencia (pp. 123-132).

El enciclopédico repertorio de formas de falta de inteligencia conceptualizadas por Kant parece recoger las distinciones terminológicas derivadas de la medicalización de la estupidez desde las últimas décadas del siglo XVIII. En efecto, la Nosologie methodique de François Boissier de Sauvages (1771), bajo la categoría de locuras o enfermedades mentales (folies), incluía el orden de la imbecilidad y la estupidez (imbecillité, bêtisse), para caracterizar la debilidad intelectual o la inaptitud a la hora de razonar y juzgar adecuadamente. En ese orden de ideas, la estupidez (stupidité, bêtisse) sería una variante de la imbecilidad en que, a las dificultades para juzgar, se sumarían la debilidad, lentitud o abolición de la facultad de imaginación y memoria para apercibirse de los objetos, así como la incapacidad para entender adecuadamente lo que se habla (Boissier de Sauvages, 1771, pp. 713-726). De modo análogo, en su Nosographie philosophique de 1798, Philippe Pinel incorporó, bajo la clase de las enfermedades nerviosas y como un tipo de vesania o lesión del entendimiento, el género del idiotismo (idiotisme). Bajo la clasificación de Pinel, en el idiota se debilitarían o anularían completamente las funciones del entendimiento e, incluso, los afectos del ánimo. En ese sentido, el cretinismo sería una especie de idiotismo extremo endémico en algunas regiones de Europa (Pinel, 1803, pp. 249-250). En su Tratado médico-filosófico de la enajenación del alma, o manía (originalmente publicado en 1801), Pinel también consideraba como una forma incurable de enajenación el idiotismo u obliteración de las facultades intelectuales y de las funciones del alma (1804, pp. 242-252).

Por su parte, en su tratado Des maladies mentales considérées sous le rapport médical, hygiénique, et médico-légal (originalmente publicado en 1838), Jean-Étienne Dominique Esquirol no solo incorporó en el lenguaje médico a la imbecilidad o al idiotismo entre las formas de la enajenación mental atribuibles a la impotencia o debilidad de las funciones intelectuales, sino que además distinguió la imbecilidad y la idiotez como especies de degradación de la inteligencia humana. Para Esquirol, la imbecilidad se caracterizaría por una conformación y organización normales, que hacen posible disfrutar de las facultades intelectuales y afectivas, aunque con un desarrollo limitado y más débil que en las personas de inteligencia normal, de modo que los imbéciles podrían pensar, hablar y recibir alguna educación. El idiotismo sería el grado máximo de falta de facultades intelectuales y morales (incluido el uso de la palabra), y representaría el estado más rudimentario de la inteligencia y la sensibilidad, debido a una organización incompleta y a un desarrollo prácticamente nulo de la sensibilidad, la atención y la memoria, de manera que solo se pueden repetir acciones por costumbre o imitación, sin guía de la razón (Esquirol, 1856, p. 297). En todo caso, aunque Esquirol incluyó el idiotismo en el lenguaje médico, no lo trataba como una 
enfermedad, sino como un estado inalterable "en el que las facultades intelectuales no han aparecido, o bien no han podido desarrollarse bastante para que el idiota haya tenido tiempo de adquirir los conocimientos relativos a la educación" (p. 295).

En el libro de Jean Baptiste François Descuret La Médecine des passions, ou, Les Passions considérées dans leurs rapports avec les maladies, les lois et la religion (originalmente publicado en 1841), encontramos una sistematización de todo este saber médico-legal sobre las supuestas enfermedades intelectuales, en el cual cada término constituye un grado descendente de la razón hacia el idiotismo pleno y congénito: la imbecilidad (imbécillité o, en latín, imbecillitas) corresponde al debilitamiento de las facultades intelectuales de individuos que tuvieron su razón cabal y pueden dar muestras momentáneas de memoria, atención o juicio; la tontería (bêtise, stultitia) consiste en una forma de idiotismo que exhibe tenues fragmentos de inteligencia y capacidad de hablar; la estupidez (stupidité, stupiditas) es la forma de idiotismo que exhibe solo algunas percepciones y sentimiento de las necesidades físicas; por último, el embrutecimiento (abrutissement, amentia) sería el estado más abyecto de la condición humana, en el cual ni siquiera se dan percepciones o sentimiento de necesidades (Descuret, 1857, pp. 147-148).

Desde las primeras décadas del siglo XX, en el pensamiento contemporáneo se ha manifestado cierta inquietud intelectual por la estupidez humana generalizada, más allá de los casos anormales de los cuales se hizo cargo el pensamiento médico-legal del siglo XIX. En su conferencia de 1937 Über die Dummheit, Robert Musil sostenía que la estupidez no puede reducirse a una falta de inteligencia o insuficiencia intelectual; al fin y al cabo, la habilidad o capacidad que solemos asociar al concepto de inteligencia varía dependiendo de la forma de vida y el contexto histórico: puede privilegiar la agudeza sensorial y agilidad física, o bien el trabajo intelectual y el raciocinio. Según Musil, ese nexo entre estupidez e incapacidad genérica explicaría la difusión de las insultantes acusaciones mutuas de estupidez. Sin embargo, en nuestras formas de vida, existirían muy variadas formas de insuficiencia intelectual o psicológica, de modo que, al menos, cabe distinguir dos tipos de estupidez: por un lado, está la estupidez simple y honesta, atribuible a la debilidad de la razón, la torpeza intelectual, la incapacidad para aprender y la pobreza de imágenes y discurso; por otro lado, se daría una estupidez pretenciosa y elevada, que no carecería de cierta inteligencia, pero asume labores desmedidas y supone cierto sentimiento desequilibrado o una colaboración insuficiente entre sentimiento y razón, de manera que puede asociarse a una educación desproporcionada, así como a la inestabilidad e infertilidad intelectuales. Así pues, para Musil, "la estupidez que se entiende con eso no es una enfermedad mental y, sin embargo, es la enfermedad más peligrosa de la mente, peligrosa hasta para la vida" (2014, p. 47). Y, puesto que toda persona puede comportarse eventualmente de un modo no demasiado prudente, o bien no encontrar el equilibrio entre el comportamiento objetivamente funcional, apropiado y competente, la estupidez puede darse en cualquiera de vez en cuando; sobre todo en condiciones de vida confusas, complejas e, incluso, constitutivamente estúpidas (Musil, 2014, pp. 41-49).

También Paul Tabori, en The Natural Science of Stupidity (originalmente publicado en 1959, y reeditado bajo el título The Natural History of Stupidity en 1993), se hace cargo del aspecto polimorfo de la estupidez humana, que se refleja en la gran cantidad de sinónimos para designarla: tontería (doltishness), confusión (muddleheadedness), incapacidad (incapacity), simpleza (hebetude), vacuidad (vacuity), fatuidad (fatuity), idiotez (idiocy), necedad (folly), entre otras muchas palabras que permiten designar o todo tipo de tontos, bobos, mentecatos e imbéciles (1993, p. 1). Como Musil, Tabori considera que la estupidez 
no concierne a algún defecto congénito en el órgano de la inteligencia o alguna imperfección incurable en las funciones mentales; más bien, involucra un mal empleo o poca utilización de nuestro instrumental para razonar y, por tanto, un problema en la persona del usuario. En ese sentido, "el prudente puede convertirse en estúpido y el estúpido en prudente" (p. 2). La estupidez tampoco se confundiría con la ignorancia, pues la abundancia de conocimientos puede encubrir la ignorancia, y la ignorancia puede convivir con la prudencia cuando no es preciso mucho conocimiento o educación formal; no obstante, la estupidez explota y agudiza la ignorancia, que se perfila, por ende, como síntoma de estupidez (p. 11). Tabori también parece compartir con Musil que la idea de que la estupidez se vincula a cierta inconsciencia de sí e incapacidad personal para autoexpresarse y lograr la cooperación de instinto o emoción y razón, con la consiguiente resistencia intelectual y la derrota del propio deseo o voluntad. Al fin y al cabo, la estupidez se manifestaría cuando se ve obstaculizada la expresión del propio deseo o voluntad, de manera que el estúpido "se abstiene de actuar (estupidez pasiva) o actúa erróneamente (estupidez activa)". De ese modo, se limita también la adquisición de conocimiento, y así se suma la ignorancia a la estupidez (p. 5). Bajo el supuesto de que los síntomas y expresiones de la estupidez son incontables, Tabori explora formas concretas de la estupidez como el prejuicio humano, la intolerancia, el fanatismo, la credulidad y la superstición, o bien las formas particulares que el estúpido asume en algunos círculos sociales limitados o contextos profesionales; su conclusión es que la estupidez resulta tan humanamente generalizada como trágicamente devastadora para la humanidad (pp. 11-15).

Las ciencias sociales y las humanidades contemporáneas han intentado dar respuesta a ese tipo de estupidez generalizada y socialmente omnipresente, vinculada a ciertos problemas en el razonamiento práctico, esto es, en la deliberación, los proyectos e iniciativa personales, que no se deja reducir a casos de deficiencia intelectual o de insuficiencia en las facultades cognitivas. Por citar algunos ejemplos, en su célebre texto sobre las leyes de la estupidez (Le leggi fondamentali della stupidità umana, originalmente publicado en 1988), Carlo Cipolla no solo establecía la difusión, distribución, elevada probabilidad y carácter sobreabundante de la estupidez humana, así como nos recordaba la peligrosidad incalculable de los estúpidos, sobre todo cuando ocupan posiciones de poder o autoridad. Además, Cipolla presentaba una teoría consecuencial y utilitarista de la estupidez, en virtud de la cual los estúpidos (stupidi) lo son porque en sus acciones y omisiones solo obtienen pérdidas o no ganan nada, y generan pérdidas o daño personal a los demás; de ese modo, se distinguen tanto de los ingenuos o incautos (sprovveduti), que sufren pérdidas personales en beneficio de otros, como de los malvados (banditi), que obtienen ventajas personales a costa de los demás y, por supuesto, de los inteligentes (intelligenti), que combinan la ganancia propia con la ventaja ajena (Cipolla, 1996). En el caso de Aaron James, sus textos sobre las características del imbécil (asshole) nos presentan la imbecilidad como un rasgo estable de personalidad que reúne una serie de condiciones: (a) el imbécil se arroga sistemáticamente una serie de ventajas particulares en las relaciones sociales; (b) tiene como motivación el firme convencimiento, aunque sea errado e injustificable, de que está en su pleno derecho y es especial; finalmente, se siente inmune ante las quejas y protestas de las demás personas. En ese sentido, el imbécil se distinguiría del estúpido que, aunque también sea desconsiderado con los demás, no tiene problemas en disculparse (James, 2016, pp. 11-13).

Finalmente, resulta digna de mención la conceptualización de la estupidez estructural (structural stupidity) por David Graeber, como se encuentra teorizada en su libro del 2015: The Utopia of Rules: On Technology, Stupidity, and the Secret Joys of Bureaucracy. En lugar de centrarse en la imbecilidad indi- 
vidual o el idiotismo privado, Graeber relaciona la estupidez estructural con las asimetrías sociales, las desigualdades sistemáticas y las formas de violencia institucionales, las cuales reproducen opciones asimétricas y sesgadas tanto para la identificación imaginativa como para la labor de interpretación de los otros y de las dinámicas sociales. En ese sentido, la burocratización puede introducir formas de ceguera estructurales y conformar un tipo de estupidez sistémica (esquemática y simplificadora), al servicio de la reproducción de estructuras muy desiguales de la imaginación y la interpretación sociales. De ese modo, la estupidez estructural resultaría indisociable de la violencia social estructural, con sus repertorios absurdos y poco razonables de decisiones arbitrarias y coactivas, que limitan o sesgan las opciones interpretativas e imaginativas de los actores sociales (Graeber, 2015, pp. 66-81).

Como se puede apreciar a través de esta reconstrucción de las conceptualizaciones de la estupidez, los significantes empleados para designar la falta de inteligencia resultan tan fundamentales y decisivos como los discursos en que esos términos se emplean y adquieren su sentido socio-histórico. En lo que respecta al léxico para la denigración de las facultades intelectuales en castellano, las ciencias del lenguaje se han hecho cargo del repertorio de significantes de la estupidez bajo tres enfoques primordiales: los estudios lexicográficos sobre el vocabulario denigratorio referente a la falta de inteligencia, los estudios pragmáticos sobre el insulto y los estudios socio-lingüísticos sobre el discurso peyorativo. Desde una perspectiva lexicográfica, ha sido posible establecer el extenso repertorio de términos para menospreciar las facultades intelectuales, pero también se han podido analizar las clases de palabras, campos semánticos, mecanismos de formación léxica y etimologías del vocabulario de la estupidez. En estudios académicos y en obras de divulgación, como el Inventario general de insultos de Pancracio Celdrán Gomáriz (1995), o bien El arte del insulto: Estudio lexicográfico de Juan de Dios Luque, Antonio Pamies, y Francisco José Manjón (1997), se reconoce la productividad del vocabulario relativo a la merma intelectual, acorde a la extensión de su referente (Celdrán, 2008, p. 27). A diferencia del productivo vocabulario de la tontería, que tiene la particularidad de admitir diminutivo y, por tanto, asumir un tono afectivo, los términos idiota, imbécil y estúpido se consideran cultismos o latinismos relativamente modernos, más marcados y graves, los cuales no admiten diminutivos (Ariza Viguera, 2009, pp. 35-36). Al analizar el léxico denigratorio coloquial, no solo encontramos este grupo de palabras inmotivadas sinónimas de tonto, que se refieren a la merma intelectual frecuentemente mediante cultismos (idiota, imbécil, cretino, etc.); también hay expresiones relativas a la incapacidad intelectual obtenidas por transferencia de sentido a partir de los campos semánticos de lo animal (burro), de lo vegetal (berzas) o de objetos inanimados (badajo), entre otros. Asimismo, se da la formación de términos por medio de sufijos (tontaina) o de la composición (tontolaba), con un marcado protagonismo de la palabra tonto como base léxica (Lisowska, 2011).

El léxico denigratorio relativo a incapacidad intelectual ( $y$, en general, el vocabulario peyorativo) se aborda también desde una perspectiva pragmática en los estudios sobre el insulto. Al fin y al cabo, el insulto puede estudiarse a través del léxico que moviliza y, también, mediante las acciones comunicativas que lleva a cabo. En ese sentido, desde el punto de vista pragmático, el insulto relativo a incapacidad intelectual realiza un tipo de comportamiento grosero, ya sea directa y lingüísticamente articulado por medio de cierta base semántica del léxico (más o menos ofensivo), o bien indirectamente comunicado, mediante la ironía o los desplazamientos de sentido (Colín Rodea, 2005, 2007). Así pues, el insulto de menosprecio intelectual se puede expresar explícitamente por medio de palabras de evaluación negativa directamente dirigidas al destinatario ( Qué tonto eres!) o indirectamente dirigidas al destinatario 
(;Qué hijos tan idiotas tienes!), aunque también puede haber una expresión implícita del insulto por medio de palabras de evaluación positiva directamente dirigidas al interlocutor ( $Q$ Qué inteligente eres!) o indirectamente enfocadas en el destinatario (;Qué hijos tan listos tienes!) (Lisowska, 2012). Por otro lado, cuando se asume una perspectiva socio-lingüística, el léxico injurioso y el insulto nos permiten inferir los tipos de defectos físicos, mentales o espirituales reprobados por la sociedad en un momento determinado. Además, las injurias pueden situarse en los contextos sociales y géneros de discurso (como los pleitos judiciales) en los cuales la agresión verbal se perfila como un elemento perturbador del orden social establecido y que amenaza la reputación ajena y la imagen pública. Asimismo, desde un enfoque socio-lingüístico resulta posible contextualizar los términos insultantes en las relaciones jerárquicas, las asimetrías y las diferencias de condición social entre quienes insultan y quienes son insultados (Tabernero Sala, 2016, 2018).

En suma, así como la conceptualización de la estupidez nos remite inevitablemente al vocabulario de la incapacidad intelectual, este léxico peyorativo solo se entiende cabalmente al considerar los modos de enunciación y discursos que dan cuenta de las insuficiencias de las facultades intelectuales. De ahí que resulte pertinente preguntarse qué transformaciones en los discursos sociohistóricos subyacen a los cambios en los repertorios léxicos para designar la merma de facultades intelectuales y cognitivas.

\section{Método}

Con el doble propósito de describir los cambios en los repertorios léxicos relativos a la incapacidad intelectual y de interpretar los discursos sociohistóricos en que ese vocabulario cobra sentido en la moderna comunidad hispanohablante, se realizó un estudio cualitativo longitudinal que aunó el análisis lexicográfico y el análisis de discurso. El análisis lexicográfico pretendió determinar cuáles han sido los términos más usuales del vocabulario de menosprecio intelectual, y cómo ha variado su frecuencia de empleo, entre los siglos XIV y XX. Adicionalmente, el análisis lexicográfico contempló una revisión de las definiciones de los principales términos de menosprecio intelectual en diferentes diccionarios de la lengua y diccionarios de sinónimos, entre los siglos XVII y XIX. Por último, a través de textos representativos que tematizaran las distintas modalidades de enunciación de la falta de inteligencia, se interpretó el contexto discursivo en que los principales términos de menosprecio intelectual se emplean y cobran sentido.

\subsection{Corpus}

Para determinar la frecuencia de uso de los términos, se tomó como muestra de referencia la totalidad de los textos contenidos en el Corpus Diacrónico del Español (CORDE), considerando el periodo entre 1401 y 1950, y en el caso del empleo reciente de los términos, entre 1951 y el año 2000, se recurrió a todos los textos del Corpus de Referencia del Español Actual (CREA) de la Real Academia de la Lengua (2020a, 2020b). Se trata de un par de corpus compuestos por documentos procedentes tanto de España como de Hispanoamérica, y que representan distintos medios (libros y prensa), temáticas (historia, religión, sociedad, derecho, etc.) y géneros (novelas, cartas, ensayos, códigos, etc.). Como se aprecia en el cuadro 1, se segmentó la muestra por siglos. 


\section{Cuadro 1}

Documentos y cantidad de palabras por siglo en los corpus CORDE y CREA (2020)

\begin{tabular}{ccccccc} 
& $\begin{array}{c}\text { Siglo XV } \\
(1401-1500)\end{array}$ & $\begin{array}{c}\text { Siglo XVI } \\
(1501-1600)\end{array}$ & $\begin{array}{c}\text { Siglo XVII } \\
(1601-1700)\end{array}$ & $\begin{array}{c}\text { Siglo XVIII } \\
(1701-1800)\end{array}$ & $\begin{array}{c}\text { Siglo XIX } \\
(1801-1900)\end{array}$ & $\begin{array}{c}\text { Siglo XX } \\
(1901-2000)\end{array}$ \\
\hline documentos & 4947 & 6005 & 3486 & 3179 & 3178 & 115930 \\
\hline palabras & 22241671 & 50620521 & 36386678 & 14490011 & 43398647 & 161322275
\end{tabular}

Fuente: elaboración propia

Del amplio vocabulario de menosprecio intelectual, se seleccionaron en el corpus solo aquellos nombres o adjetivos (en todos los géneros, números y variantes ortográficas) que se refieren directamente a una inteligencia o conocimiento insuficiente, dejando de lado tanto las expresiones metafóricas como los vocablos derivados o compuestos relativos a la incapacidad cognitiva. Además, solo se analizaron los términos con un mínimo de 2000 apariciones en todo el corpus, a saber: necio, tonto, ignorante, estúpido, bobo, idiota, imbécil e insensato.

Los diccionarios de siglos pasados que se consultaron para el análisis lexicográfico de las entradas seleccionadas fueron los siguientes: el Tesoro de la lengua castellana de Sebastián de Covarrubias (1611), el Diccionario de la lengua castellana compuesto por la Real Academia Española (1783), el Diccionario de la lengua castellana de la Real Academia Española (1832) y el Diccionario de sinónimos de la lengua castellana por Pedro María de Olivé (1843).

En cuanto a los textos representativos de los diferentes discursos sobre la merma intelectual, se consideraron algunos textos que tematizan explícitamente los conceptos de necedad, idiotismo y tontería: las "Invectivas contra los necios" atribuidas a Francisco de Quevedo (posiblemente escritas a finales del siglo XVI y comienzos del XVII); la sección sobre el "Idiotismo o idiocia" del Diccionario de los diccionarios de medicina publicados en Europa, traducida y adaptada por Manuel Jiménez (1843); finalmente, el ensayo de José Ferrater Mora titulado "Variaciones sobre la tontería” (fechado en 1959).

\subsection{Procedimiento}

Mediante la función de consulta a la base de datos de los corpus CORDE y CREA, se registraron, por siglo, las frecuencias de empleo de cada uno de los términos de menosprecio intelectual considerados. Por medio de una estadística descriptiva básica, se analizaron las diferencias de frecuencias por siglo, recurriendo a tablas de contingencia, y se representaron los datos en gráficos de barras.

El análisis lexicográfico cualitativo de las definiciones de diccionario consideró los rasgos contenidos en las definiciones de los vocablos y las categorías empleadas para significar la facultad intelectual afectada en cada caso, así como las diferencias establecidas entre los sinónimos. Una vez identificados los cambios en frecuencia y significado de los términos de menosprecio intelectual analizados, se procedió a contextualizar su empleo en algunos discursos representativos que tematizan explícitamente ese léxico, y se interpretaron los temas asociados, las oposiciones nocionales y el marco discursivo de enunciación de cada vocablo. 


\section{Resultados}

\subsection{Frecuencia de empleo del léxico de menosprecio intelectual}

Al registrar la frecuencia de empleo de cada uno los términos analizados (necio, tonto, ignorante, estúpido, bobo, idiota, imbécil e insensato) en el conjunto del corpus analizado, se pone de manifiesto que los vocablos para designar explícita y convencionalmente la incapacidad intelectual más empleados por la moderna comunidad hispanohablante son necio, tonto e ignorante, como se aprecia en el gráfico 1.

\section{Gráfico 1}

Porcentaje de empleo de cada uno de los términos de menosprecio con respecto al total de términos analizados entre 1401 y 2000

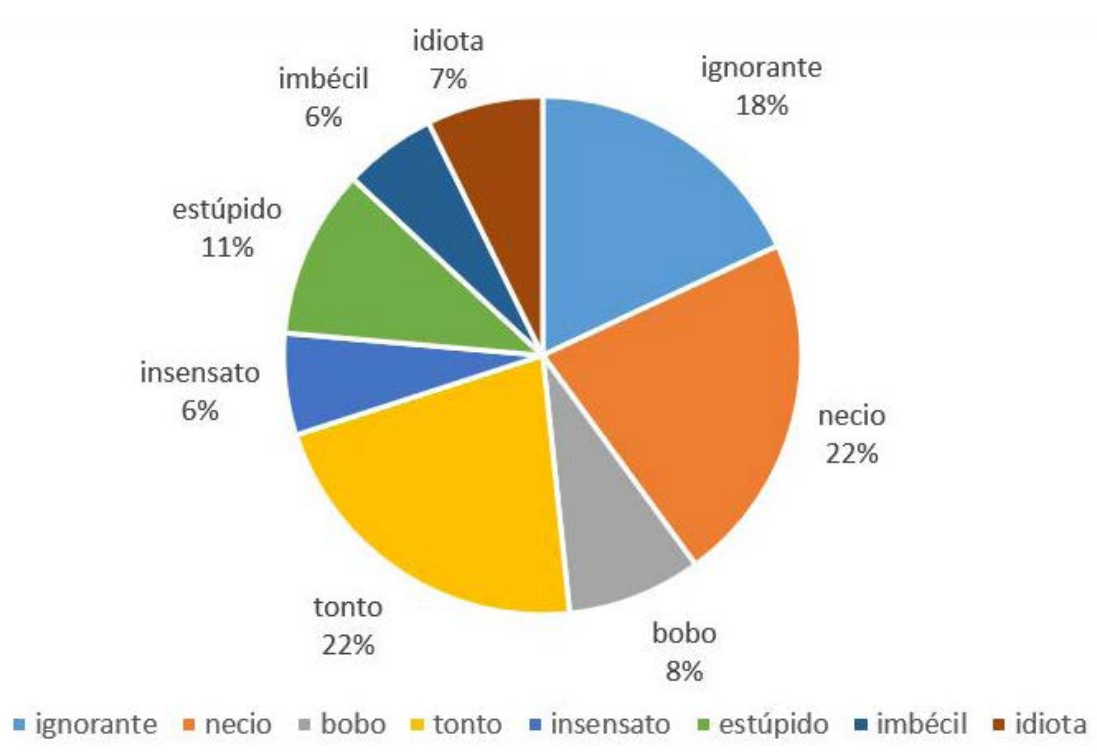

Fuente: elaboración propia

Cuando comparamos entre siglos el porcentaje de frecuencia de empleo de cada uno de los términos analizados, se reconocen diferencias significativas en el moderno uso del léxico de menosprecio intelectual $(\chi 2=13464, d f=35, p<0,001)$, como se evidencia en el gráfico 2 . 


\section{Gráfico 2}

Porcentajes de empleo por siglo de cada uno de los términos con respecto al total de términos analizados

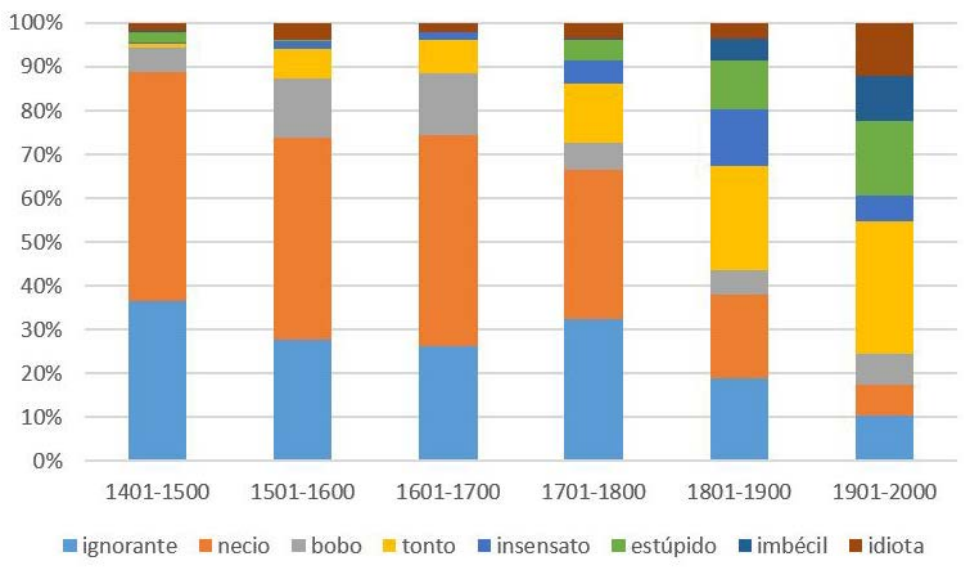

Fuente: elaboración propia

En cuanto al término más utilizado en cada uno de los siglos, el término necio fue el más empleado entre los siglos XV y XVIII (corresponde casi a la mitad del léxico de menosprecio intelectual analizado en cada siglo), y en los siglos XIX y XX predomina el vocablo tonto (con valores de $23.8 \%$ y $30.2 \%$, respectivamente). Si analizamos la trayectoria de los distintos significantes de incapacidad intelectual, se observa que el uso de términos como necio, ignorante o bobo disminuyó significativamente a partir del siglo XVIII, mientras que el uso de los vocablos tonto, estúpido, idiota e imbécil se ha ido incrementando hasta alcanzar sus niveles más altos en los siglos XIX y XX. En ese sentido, puede hablarse de una creciente diversificación del léxico del insulto empleado por la moderna comunidad hispanohablante en los siglos XIX y XX. Por otra parte, al calcular la frecuencia de cada término por millón de palabras del corpus, se aprecia una mayor presencia del léxico de menosprecio intelectual explícito y codificado en algunos siglos, como se observa en el gráfico 3. 


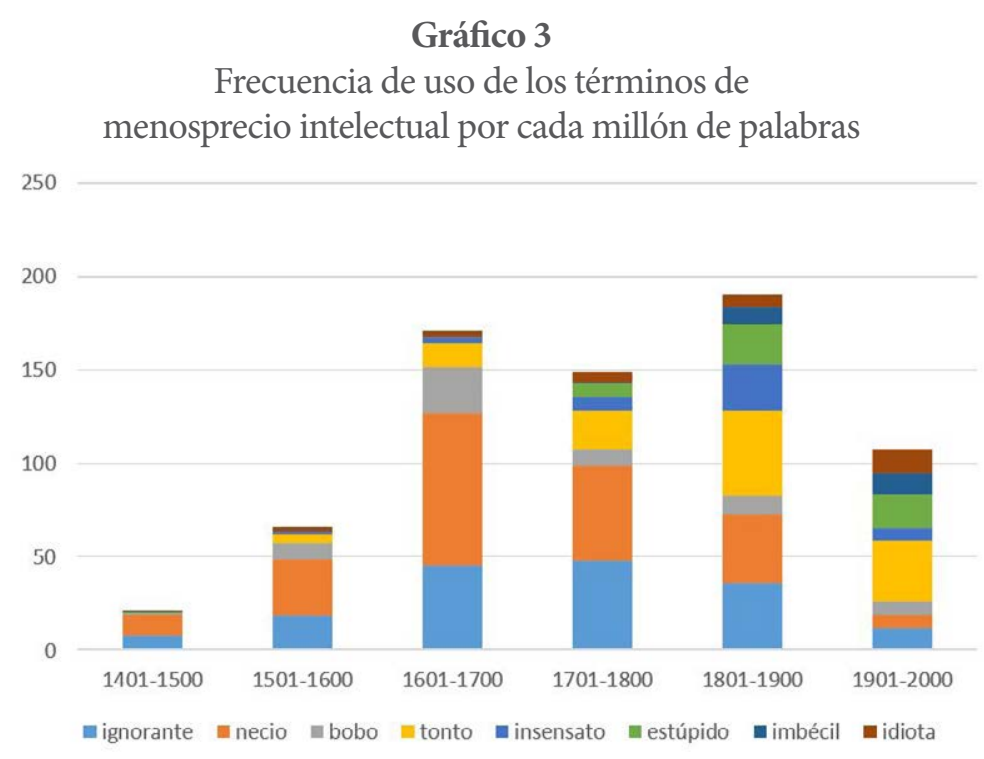

Fuente: elaboración propia

Concretamente, los siglos XV y XVI presentan menos frecuencia del léxico analizado (21.16 y 65.91 términos por millón de palabras), mientras que en los siglos XIX y XVII parece alcanzarse el máximo empleo de vocabulario de menosprecio intelectual (190.48 y 171.18, respectivamente).

\subsection{Definiciones del vocabulario explícito y codificado de menosprecio intelectual}

Cuando consultamos en diccionarios escritos entre el siglo XVII y el siglo XIX el significado atribuido a los términos analizados (necio, tonto, ignorante, estúpido, bobo, idiota, imbécil e insensato), llama la atención la diferencia en las definiciones otorgadas al léxico de menosprecio intelectual. En el Tesoro de la lengua castellana de Sebastián de Covarrubias (1611), los rasgos más repetidos en el léxico explícito de menosprecio intelectual son la falta de saber o ignorancia, así como la falta de discurso, como se aprecia en el cuadro 2 (no incluye los términos sin entrada, como estúpido, ignorante, imbécil e insensato).

\section{Cuadro 2}

Rasgos contenidos en la definición de los términos de menosprecio en el diccionario de Covarrubias (1611)

\begin{tabular}{|c|c|c|c|c|}
\hline & bobo & idiota & necio & Tonto \\
\hline Simple & & & & + \\
\hline Tardo & + & & & \\
\hline Falto de saber & & + & + & \\
\hline Falto de discurso & + & + & & \\
\hline Falto de entendimiento o razón & & & & + \\
\hline
\end{tabular}

Fuente: elaboración propia 
En una fuente del siglo XVIII como el Diccionario de la lengua castellana compuesto por la Real Academia Española (1783), se sigue observando cuánto pesa la falta de saber en el menosprecio intelectual (de hecho, varios términos incluyen ignorante o necio en su definición); aunque también cobra importancia la falta de artificio (la condición de simple o, incluso, de bruto), la falta de sentido (o discernimiento) y la falta de razón. Así se reconoce en el cuadro 3. Curiosamente, aun cuando el diccionario incluye el término imbécil, este no se refiere a alguna incapacidad intelectual, sino solo significa debilidad o languidez; por eso no figura en el cuadro.

\begin{tabular}{|c|c|c|c|c|c|c|c|}
\hline & meno & $\begin{array}{l}\text { asgos en } \\
\text { cio en el }\end{array}$ & $\begin{array}{l}\text { Cuac } \\
\text { efinicic } \\
\text { cionari }\end{array}$ & $\begin{array}{l}\text { los térm } \\
\text { la Real A }\end{array}$ & $\begin{array}{l}\text { s de } \\
\text { emia (178 }\end{array}$ & & \\
\hline & bobo & estúpido & idiota & ignorante & insensato & necio & Tonto \\
\hline Simple & & & & + & & & \\
\hline Bruto & & + & & & & & \\
\hline Terco & & & & & & + & \\
\hline Falto de capacidad & + & + & & & & & \\
\hline Falto de saber & & & + & + & + & + & + \\
\hline lletrado & & & + & & & & \\
\hline $\begin{array}{c}\text { Falto de sentido o } \\
\text { juicio }\end{array}$ & & + & & & + & & + \\
\hline Falto de prudencia & & & & & & + & \\
\hline $\begin{array}{l}\text { Falto de entendi- } \\
\text { miento }\end{array}$ & + & & & & & & + \\
\hline Falto de razón & & & & & + & + & + \\
\hline
\end{tabular}

Fuente: elaboración propia

En el equivalente del siglo XIX, el Diccionario de la lengua castellana de la Academia Española (1832), al caracterizar la incapacidad intelectual, sigue predominando la condición de falta de saber o la ignorancia, aunque se acentúa la diferenciación de rasgos relativos a la falta inherente de capacidad intelectual y de facultades cognoscitivas (debilidad de espíritu o genio, falta de entendimiento, falta de razón, falta de discernimiento, falta de prudencia o falta de comprensión), así como desaparecen las carencias relacionadas con el lenguaje. Puede apreciarse este cambio relativo en el cuadro 4.

\section{Cuadro 4}

Rasgos en la definición de los términos de menosprecio en el diccionario de la Real Academia (1832)

\begin{tabular}{|c|c|c|c|c|c|c|c|c|}
\hline & bobo & estúpido & idiota & ignorante & imbécil & insensato & necio & tonto \\
\hline Rústico & & & + & & & & & \\
\hline Terco & & & & & & & + & \\
\hline Fatuo & & & & & & + & & + \\
\hline Débil de espíritu & & & & & + & & & \\
\hline
\end{tabular}




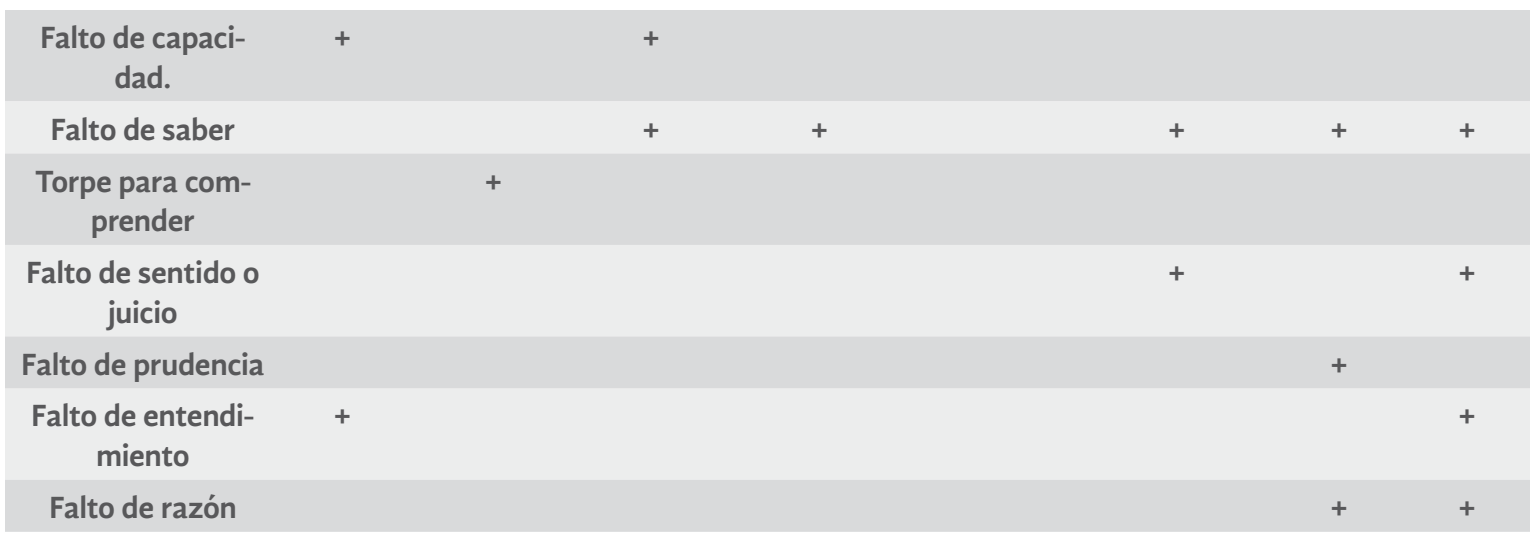

Fuente: elaboración propia

Para describir la diferenciación decimonónica del léxico explícito de menosprecio intelectual, resulta instructivo el Diccionario de sinónimos de la lengua castellana escrito por Pedro María de Olivé (1843). En esta obra, la caracterización del ignorante y del necio siguen girando en torno a la falta de saber; aunque al ignorante le falta aplicación e instrucción, mientras que el necio sabe las cosas mal, carece de discernimiento, es incapaz de pensar por sí mismo (como el bobo) y lo hace todo al revés (De Olivé, 1843, p. 230). El bobo comparte así con el necio su incapacidad para pensar por sí mismo, marcada por la credulidad y la incapacidad para comprender (pp. 44-45). Cae en la definición de tonto quien ignora, carece de capacidad de conocer y discernimiento, y es indiferente ante todo (salvo las nimiedades); en ese sentido, el tonto no tiene disposición natural por su organización, o bien se ha entontecido por la educación o por circunstancias de la vida (pp. 230 y 165). Como el tonto, el insensato carece de sensatez, entendimiento y razón, de manera que se asemeja también al necio e, incluso, al imbécil, o sea, el inepto y menguado que carece de inteligencia y juicio (p. 194). Entre los términos del léxico de menosprecio intelectual, hay algunos casos de deficiencia congénita, como el idiota, cuya ignorancia suprema, atribuible a un defecto natural en los órganos que sirven a las operaciones del entendimiento, se asocia a la incapacidad de combinar ideas. De Olivé formula en un lenguaje cercano al discurso médico la diferencia entre el idiota y el imbécil: "el idiota nace, y el imbécil lo llega a ser, bien por alguna causa extraña, o por su mala educación o por el aire de su país natal. El idiota lo es siempre: al imbécil se le puede curar" (p. 231). La condición más bestial y animalizada del ser humano es la del estúpido, que carece de sentimientos y a quien nada conmueve (a diferencia del idiota, que no puede concebir) (p.47); se trata de una forma de total falta de inteligencia atribuible a la organización natural:

El estúpido carece enteramente de inteligencia, es como inferior a las mismas bestias, pues ni aun el instinto de estas tiene. Todo lo espiritual le falta; solo tiene lo material de los brutos y sus apetitos, y en la clase de estos solo se le puede comparar con las más torpes y de muy limitado instinto: son como las tortugas en la especie humana. (De Olivé, 1843, p. 165)

El matizado repertorio de rasgos atribuidos en el siglo XIX a las distintas formas de incapacidad intelectual contrasta con las definiciones contemporáneas del léxico de menosprecio intelectual, que se sirven 
básicamente del término tonto para caracterizar gran parte del vocabulario de la falta de inteligencia, como ocurre en las entradas bobo, insensato, idiota e imbécil (Real Academia Española, 2020c).

\subsection{Discursos del menosprecio intelectual}

Las variaciones en los repertorios del léxico referente a falta de inteligencia y los cambios en las definiciones de los términos se entienden adecuadamente en virtud de ciertos desplazamientos en los discursos sociohistóricos de menosprecio intelectual. En ese sentido, cabe diferenciar un discurso moral de la necedad, un discurso médico-legal del idiotismo y un modo de enunciación coloquial de la tontería. Presentan distintos modos de organización simbólica, en la medida en que la tematización de la incapacidad intelectual responde a distintos marcos discursivos, series conceptuales y oposiciones nocionales.

\subsubsection{El discurso moral de la necedad}

El vocabulario bíblico de la estulticia (stultus, stultitia), que en los libros sapienciales permitía designar el conocimiento e inteligencia insuficientes, fue traducido al castellano con el léxico de la necedad, aunque también de la locura, como se aprecia en la traducción de la Biblia por Cipriano de Valera (1602). En ese sentido, De Valera suele traducir por necio el término insipiens, asi como stultus por loco: "El hombre necio [insipiens] no sabe y el loco [stultus] no entiende esto" (De Valera, 1602, Salmos XCII: 7). En esta traducción, tanto el stultus como el insipiens se contraponen al sabio dotado de sapientia. No obstante, en la literatura moral y la exégesis religiosa de la primera modernidad, el vocabulario de la stultitia se traducirá frecuentemente como necedad, y se mantendrá la oposición bíblica sapiencial entre el necio y el sabio. En la sección de su Monarquía mística de la Iglesia titulada "De la miseria del entendimiento poco avisado", Lorenzo de Zamora (1603) nos recuerda que desde la Antigüedad se ha considerado "a la sabiduría por el mayor de los bienes y a la necedad por el mayor de los males" (p. 472), y en su texto traduce tanto stultus como insipiens por necio. En continuidad con la moral sapiencial bíblica, De Zamora contrapone al sabio y al necio: el sabio tiene interior y exterior, ojos en la cabeza para contemplar y especular; el necio solo tiene exterior (como una vaina sin contenido valioso), con la cabeza puesta en los ojos y en lo que ve externamente. Además, la necedad se presenta como una condición natural e incurable, agravada por la fatuidad y la terca incapacidad para guardar silencio, de manera que los necios resultan ineptos para asumir cargos y dignidades (De Zamora, 1603, pp. 472-476).

También Juan Huarte de San Juan, en su obra de 1594 titulada Examen de los ingenios para las ciencias, había traducido el vocabulario de la stultitia en términos de necedad. Tras asociar el ingenio al entendimiento claro, la capacidad de aprender, la intelección de lo esencial, así como la sabiduría y la prudencia, Huarte de San Juan examina los diferentes tipos de inhabilidad para el conocimiento y la ciencia: la incapacidad absoluta para engendrar conceptos ni concebir principios, con la cual nada se puede hacer, debido a su cercanía a la animalidad; la inhabilidad de quienes pueden concebir principios y sacar conclusiones, pero solo de modo voluble y desmemoriado; la inhabilidad de los que aprenden letras y tienen algo de ingenio, de modo que pueden concebir y retener principios y sacar conclusiones, pero están sumidos en la confusión intelectual; por último, la reproducción inerte de alguna doctrina concebida consistentemente 
y retenida con firmeza, aunque sin capacidad para entender o saber el porqué de las cosas (Huarte de San Juan, 1594, pp. 38-42). En su libro, Huarte de San Juan nos recuerda hasta qué punto es injurioso llamar a alguien falto de ingenio, pues la necedad hace imposible el aprendizaje y la sabiduría, e impide la felicidad y la honra (p. 36); no obstante, asume que hay que responder a la necedad para que no se tenga por sabia, pues "no hay cosa más perjudicial en la república que un necio, con opinión de sabio; mayormente si tiene algún mando y gobierno" (p. 38).

En las "Invectivas contra los necios" (textos escritos en torno a 1600 y atribuidos a Francisco de Quevedo) encontramos un giro distinto en este discurso moral sobre la necedad. En un marco discursivo satírico (que no es más que el relato moral del fracaso de la sabiduría), se diferencian tres categorías de necios: los necios en sentido propio requieren de algún trato para descubrir cuánto saben y poner de manifiesto su necedad; los majaderos son una clase de necios que se reconocen en cuanto comienzan a hablar y entendemos lo que dicen; finalmente, los modorros se identificarían a simple vista, solo por su traje y compostura. El relato satírico de la genealogía de la necedad más evidente pone de manifiesto los orígenes y progenie de esta condición: el tiempo perdido y la ignorancia, la juventud y el pecado, la irreflexión y la imprevisión, el conformismo y la postergación, el salvar las apariencias y el excusarse, la vanidad, la desdicha o la dispensación, entre otros vicios de la condición humana (De Quevedo, 1852, pp. 443-446). Por otra parte, en el texto "Origen y definiciones de la necedad", se define explícitamente la condición del necio: "Necedad se llama y es todo aquello que se hace o dice en contra o repugnando a las costumbres de cortesía o lenguaje político" (p. 448). Como se puede apreciar en la definición y en los ejemplos, la necedad se contrapone a la prudencia práctica y la discreción, tanto como a las buenas costumbres y el trato cortés: sería tan necio el comportamiento indecoroso, torpe, pretencioso e impertinente, como la falta de cordura, prudencia, inteligencia, ingenio, memoria, conocimiento o tino (De Quevedo, 1852, pp. 448-451). En suma, la sátira quevedesca no es sino un momento de inversión irónica de cierta jerarquía moral y religiosa (así como de una visión comprehensiva de la vida buena altamente articulada y organizada simbólicamente) en que la sabiduría subordina y contiene a la necedad, del mismo modo que el bien al mal, o bien la virtud al vicio. Hasta prácticamente el siglo XVIII, se mantuvo vigente en la comunidad hispanohablante esta jerarquización discursiva en la cual el ideal normativo radica en la sabiduría lograda, frente a las muy diferentes manifestaciones de la necedad humana.

\subsubsection{El discurso médico-legal del idiotismo}

Desde el siglo XVIII, comienzan a difundirse en la comunidad hispanohablante ciertos cultismos del léxico de menosprecio intelectual, como idiota o estúpido, mediante los cuales los intelectuales ilustrados designaron distintas formas del prejuicio, la ignorancia y el error. En su Teatro crítico universal (publicado entre 1742 y 1760), el padre Benito Jerónimo Feijoo y Montenegro puso frecuentemente en circulación los calificativos idiota o estúpido en sus particulares discursos varios en todo género de materias, para desengaño de errores comunes (subtítulo de la obra). En su discurso ilustrado afirmó, por ejemplo: "No solo lo raro pasa en el vulgo por milagroso, aun los efectos comunes de la naturaleza gozan este fuero entre la gente idiota" (Feijoo, 1863, p. 119). 
A través de las traducciones al castellano de los textos de Pinel y Esquirol sobre las enfermedades mentales, a comienzos del siglo XIX se consolidó en la comunidad hispanohablante un registro médico-legal del léxico del menosprecio intelectual. De esta manera, se consumaba la naturalización de la falta de inteligencia, al mismo tiempo que la normatividad del discurso moral daba paso a la norma de la clasificación nosológica y al contraste entre lo normal y lo patológico. En el Diccionario de los diccionarios de medicina publicados en Europa, traducida y adaptada por el Dr. Manuel Jiménez (1843), los términos idiota, imbécil y estúpido aparecen profusamente bajo la categoría de la enajenación mental. Siguiendo a Pinel, Esquirol y otros autores, Jiménez caracteriza el idiotismo o la idiocia como un tipo de enfermedad mental en que "las facultades intelectuales, los sentimientos morales y los instintos, originalmente nulos, o detenidos en una época variable de su desarrollo, no llegan a tener el grado necesario a la conservación del individuo y a la moralidad de sus actos" $(1843$, p. 4). Jiménez también recoge algunas de las distinciones del saber médico sobre la enfermedad mental, de manera que se pueden reconocer distintos grados de idiocia. Así, el idiotismo congénito (más completo, ya que se daría por privación de facultades cerebrales) se distingue del adquirido o accidental, que presupone cierto desarrollo normal del instinto y de las facultades intelectuales y morales. La idiocia más completa y deplorable se caracteriza por la indiferencia al movimiento, la sensibilidad nula y la fisonomía estúpida. Por lo demás, habría idiotas con instintos, sensibilidad obtusa y capacidad de movimiento, aunque en un grado muy débil, cercano al de los animales. Los imbéciles constituirían una clase de idiotas que presentan "operaciones intelectuales débiles y limitadas e instintos muy pronunciados” (p. 9), con sensaciones precisas y una facultad perceptiva parcial, atención débil, entendimiento limitado, un círculo de ideas reducido, sentimientos morales subordinados a los instintos y con capacidad para ocuparse en tareas simples. En su diccionario, Jiménez expone distintos aspectos orgánicos, cerebrales, corporales y conductuales (como el descaro y onanismo de los imbéciles), asociados naturalmente a los diferentes tipos de idiocia; además, señala las causas naturales del idiotismo, y concluye que, desde el punto de vista de la anatomía patológica, no hay tratamiento ni cura posible para este estado mental (pp. 10-13). En cuanto a la estupidez, Jiménez considera que no se ha de confundir con la idiocia, y la clasifica como una "abolición rápida más o menos completa, apirética y curable de todas las facultades intelectuales y morales, de los instintos y de los movimientos" (p. 21). A diferencia del idiotismo, la estupidez resulta repentina, curable y se vincula a desórdenes orgánicos que provocan la percepción disminuida, la falta de vivacidad intelectual, la dificultad para moverse y hablar; aunque también las impresiones anímicas intensas, como el terror o la euforia, podrían desencadenar la estupidez (pp. 23-25).

En el discurso de la medicina legal, estas distinciones nosológicas se traducen en grados de responsabilidad e imputabilidad. Como afirmaba el Dr. Pedro Mata en su Tratado de medicina y cirugía legal:

Si el sujeto sometido a nuestro examen es un idiota, es evidente que no estaba en uso de su razón, cuando se supone que ejecutó el acto que es asunto judicial. Los idiotas no tienen nunca razón; su organización, causa de su locura, no les consiente intervalos lúcidos. ... Si es un imbécil, y en especial de las categorías en que la inteligencia es rudimentaria e incompleta, tampoco pudo estar en el uso de su razón por iguales motivos que el idiota. (Mata, 1857, p. 291)

En fin, el discurso médico-legal desplegó todo un léxico técnico de menosprecio intelectual en torno a cierta oposición nocional: la normalidad constituye el significante del valor discursivo, 
mientras lo patológico de la enfermedad, incluida la enfermedad mental, se perfilan como aspectos negativos. Así pues, lo peor sería la enfermedad congénita o incurable. Con la naturalización de la falta de inteligencia como una enfermedad mental (bajo los distintos grados de idiotismo, imbecilidad o estupidez), la medicina legal del siglo XIX consagró, como norma, la autoconservación individual y la preservación de la salud orgánica y mental, más que el logro de una sabiduría lograda que pudiese verse moralmente amenazada por la necedad.

\subsubsection{La enunciación coloquial de la tontería}

El léxico de la tontería no tiene un origen culto que se pueda remontar a algún discurso cultural simbólicamente organizado, como ocurre con la oposición nocional bíblica entre sabio y necio, o bien con las distinciones nosológicas del discurso médico-legal entre diferentes categorías de idiota. Incluso en su formación, el término tonto parece consistir en una creación expresiva basada en el juego de la simple repetición, como plantea Joan Corominas en su diccionario etimológico (1987, p. 573). Sin embargo, el vocablo tonto es el más productivo del repertorio léxico para referirse a la incapacidad intelectual; ha generado una gran cantidad de derivados o compuestos, y se encuentra presente en numerosos refranes y dichos populares (Celdrán, 2008, p. 27; Lisowska, pp. 263-264). Esta productividad léxica del término tonto parece inseparable de las opciones de reapropiación del vocablo en la comunicación coloquial, en las interacciones dialógicas cotidianas y en la polifonía de la cultura popular. Como argumentó Bajtin, la cultura popular y la comunicación cotidiana han explotado tradicionalmente la ambivalencia de la tontería (por un lado, considerada injuriosa; por el otro, transgresora y directa), para subvertir las reglas, las convenciones y el orden simbólico del discurso oficial (1988, pp. 233-234). No en vano, el bobo o el tonto han desempeñado tradicionalmente la función simbólica de doble paródico del orden soberano (como bufones de la corte) y de la ortodoxia consuetudinaria (en tanto que personajes de comedia). En ausencia de una jerarquización intelectual que permita subordinar la necedad a la sabiduría, o bien de criterios médico-legales para distinguir la salud mental del idiotismo patológico, el léxico de la tontería parece haber expandido en la modernidad tardía sus dominios a todo el campo semántico de la incapacidad intelectual.

En un ensayo de 1959 titulado "Variaciones sobre la tontería”, el filósofo José Ferrater Mora reflexionaba sobre el aspecto trivial, cotidiano y omnipresente de esa condición humana, que no se identifica con la estupidez (reverso del ingenio), con la simpleza (a menudo genuina y auténtica) o con el desatino disparatado (divertido e instructivo). Semejante a la bobería, la tontería se distinguiría por sus pretensiones incumplidas y vanas: "una estupidez que pretende ser talentosa; una simpleza que pretende ser sagaz; un desatino que pretende ser cuerdo" (Ferrater Mora, 1996, p. 123). Sin disimular sus pretensiones, la tontería se presenta directamente y tal cual es, y lo hace de modo profuso y envolvente. Ferrater Mora ejemplifica esta banalidad de la tontería a través de ciertos ejemplos que circulan en los medios de comunicación contemporáneos: las contradicciones flagrantes e inútiles que se encuentran en algunas publicaciones; la retórica odiosa, recargada y torpe, atribuible a la negligencia en desmedro de la claridad y precisión; la incomprensión terca y desinformada, que puede manifestarse a través de generalizaciones falaces; por último - y como quintaesencia de la tontería contemporánea- la trivialidad omnipresente, persistente, abruma- 
dora y previsible, que se reproduce y circula sin límites en los medios de comunicación (como ocurre con las estereotipadas descripciones mediáticas de las culturas nacionales) (pp. 124-131). En suma, el léxico de la tontería resulta tan multiforme en su enunciación y caracterizaciones como lo es en sus manifestaciones. Además, a través de su omnipresente circulación coloquial deviene insignificante, trivial y banal, en ausencia de un marco discursivo simbólicamente organizado que permita algún tipo de jerarquización intelectual o categorización experta. A estas alturas, la enunciación del léxico de la tontería ni siquiera resulta transgresora del discurso oficial, aunque nunca fue más explícita y mediática.

\section{Discusión y conclusión}

La actual conceptualización - frecuentemente ensayística - de las modalidades y condiciones de la estupidez puede matizarse notablemente cuando estudiamos los léxicos de menosprecio intelectual, así como los discursos en que ese vocabulario explícito se enuncia y tematiza en una comunidad idiomática. De nuestra investigación lexicográfica sobre los términos explícitos de menosprecio intelectual más frecuentes en la comunidad hispanohablante, puede concluirse cierto predominio histórico del léxico relacionado con cierta falta de saber, ciencia o sabiduría (ignorante, necio) y del vocabulario coloquial referente a la falta de inteligencia práctica (tonto, bobo), por sobre los cultismos asociados a la dimensión mental de la falta de intelecto (insensato, idiota, imbécil, estúpido). En todo caso, cabe reconocer diferencias significativas en el empleo del léxico explícito de menosprecio intelectual en la moderna comunidad hispanohablante: hasta el siglo XVIII, parecen haber predominado los significantes de menosprecio intelectual relacionados con la falta de conocimiento o saber (necio, ignorante) y, en menor medida, con el personaje popular del bobo; pero, en los siglos XIX y XX, se aprecia una notable diferenciación del léxico de menosprecio intelectual, un incremento de los cultismos relacionados con la falta de inteligencia personal (estúpido, idiota, imbécil e insensato, aunque el uso de este último término disminuye en el siglo XX), así como un incremento y predominio final del término más coloquial para designar la falta de inteligencia práctica (tonto).

El análisis lexicográfico cualitativo de las definiciones de ese vocabulario de menosprecio intelectual, en algunos diccionarios publicados entre los siglos XVII y XIX en el ámbito hispanohablante, confirma aparentemente las conclusiones obtenidas a partir de las frecuencias de empleo: aunque en las definiciones de diccionario del léxico explícito de menosprecio intelectual predomina el énfasis en la falta de conocimiento o saber, hay una creciente diferenciación de los rasgos léxicos relativos a la falta de facultades intelectuales naturales de la mente humana. Podría hablarse, pues, de cierta psicologización o mentalización del léxico explícito de menosprecio intelectual (si bien en los diccionarios contemporáneos el término que define a casi todos los demás por sinonimia es tonto). En ese sentido, algunos diccionarios decimonónicos de sinónimos parecen recoger las sutiles distinciones del saber médico-legal de la época relacionadas con la malformación o degeneración de las facultades intelectuales de la mente humana. La psicologización o mentalización del léxico de menosprecio intelectual cobra sentido al considerar los discursos socioculturales que enmarcaron el empleo de ese léxico. Junto al tradicional discurso moral acerca de la necedad como ausencia de la sabiduría lograda (simbólicamente organizado mediante cierta jerarquización intelectual), encontramos en la cultura moderna un discurso médico-legal que clasifica nosológicamente los defectos de las facultades intelectuales en función de su carácter patológico y condiciones naturales. Además, cabe 
identificar un modo coloquial y banal de enunciar la tontería, que parece haberse impuesto en la cultura contemporánea. Así, a través de los desplazamientos y cambios en los léxicos y discursos de menosprecio intelectual se perfilan en negativo ciertas trayectorias de la deriva intelectual moderna, así como se esbozan los distintos referentes normativos de la cultura hispanohablante: una visión comprehensiva de la vida buena asociada a la sabiduría moral, una concepción naturalizada de la normalidad en términos de salud integral (orgánica y mental), o bien la contemporánea ausencia de guiones morales o criterios normativos en una cultura marcada por la banalidad y la insignificancia.

En ese sentido, nuestro estudio lexicográfico y discursivo sobre las transformaciones en el vocabulario explícito de menosprecio intelectual parece avalar y concretar las tesis ensayísticas de Musil (2014) respecto a la irreductibilidad de la estupidez a la falta de inteligencia, debido a las variaciones que experimenta la concepción de inteligencia según el contexto socio-histórico. En efecto, el menosprecio intelectual no se expresa en el mismo léxico cuando el discurso hegemónico radica en alguna visión moral comprehensiva de la vida buena y de la jerarquización intelectual de la sabiduría y la necedad, o bien cuando se inscribe en la matriz clasificatoria del discurso médico-legal bajo criterios de salud normal o enfermedad mental. Asimismo, nuestra reconstrucción de los discursos del menosprecio intelectual nos permite establecer relaciones entre algunas de las obras más conocidas de la literatura de la estupidez (los elogios de Erasmo o Jean Paul, entre otros): como sus equivalentes en la comunidad hispanohablante (por ejemplo, las "Invectivas contra los necios" atribuidas a Quevedo), este tipo de textos entronca con cierta tradición satírica sobre los fracasos de la inteligencia humana y, en última instancia, remite al discurso moral de la necedad arraigado en los libros sapienciales de la Biblia. Por otra parte, nuestro estudio profundiza las apreciaciones de Tabori (1993) sobre el carácter no solo polimorfo, sino también polifónico de la estupidez humana, con tantos nombres como voces y expresiones. En cuanto a los estudios lingüísticos, esta investigación confirma las observaciones de algunos especialistas respecto a la productividad léxica del vocablo tonto (Celdrán, 2008, p. 27; Lisowska, pp. 263-264), y nos permite dar cuenta de la multiplicación de empleos y de la volubilidad semántica del léxico de la tontería en virtud del contexto comunicativo coloquial y popular en que el vocablo tonto y sus variaciones se enuncian cotidianamente.

Nuestro estudio deja pendiente una interrogante que no habrá pasado desapercibida al lector atento: ¿por qué en algunos siglos se registra más frecuencia de vocabulario explícito de menosprecio intelectual? En la medida en que el léxico de menosprecio intelectual suele emplearse para el insulto, y ya que deshonra uno de los atributos más valorados socialmente como constitutivos de la dignidad personal, cabría pensar que en algunos periodos históricos hay un especial celo y sensibilidad ante este tipo de injuria, lo cual se traduce en su codificación legal como delito y en sanciones a veces gravosas tras los pleitos por difamación. En ese orden de ideas, Cristina Tabernero nos ha recordado cuán significativas resultan las leyes recogidas en los fueros medievales, para entender la repercusión social de la injuria; y lo mismo ocurre con los numerosos procesos judiciales modernos por injurias (2016, pp. 252-257). No obstante, los altibajos históricos en la frecuencia del vocabulario explícito de menosprecio intelectual parecen invitarnos a considerar otros aspectos sociohistóricos. Aventuro especulativamente algunos. La mayor presencia de léxico explícito de menosprecio intelectual podría vincularse a la presencia de profundos conflictos culturales y disonancias cognoscitivas atribuibles a la presencia de varios sistemas de creencias, doctrinas comprehensivas o repertorios ideológicos; en esos contextos, se lidiaría con la incertidumbre intelectual mediante una valoración peyorativa tanto de las ideas ajenas como de quienes 
las profesan. Además, podríamos aventurar que los conflictos de ideas se intensificarían no solo como consecuencia de transformaciones decisivas en la división del trabajo intelectual, sino también debido a la erosión de jerarquizaciones intelectuales en el contexto de la individualización de las formas de pensamiento, así como de la multiplicación, masificación y fragmentación de las creencias colectivas. Eso se insinúa en esa parodia de novela de formación burguesa (o Bildungsroman de la imbecilidad y del repetido fracaso intelectual) que es Bouvard et Pécuchet, concretamente en su diccionario de ideas a la moda: "Imbéciles. Los que no piensan como uno" (Flaubert, 1978, p. 333). Por supuesto, son solo tesis especulativas, pero podrían dar cuenta de la mayor presencia de vocabulario explícito de menosprecio intelectual en algunos momentos históricos intelectual y culturalmente convulsos de la comunidad hispanohablante (como el siglo XVII o el siglo XIX). Quizá la mayor presencia de discursos de menosprecio intelectual se deba a un efecto acumulativo de estos aspectos: menor penalización social y jurídica de la injuria, conflictos intelectuales decisivos y erosión de la jerarquización intelectual tradicional. El asunto queda pendiente para futuros estudios históricos sobre el menosprecio intelectual.

\section{Referencias}

Ariza Viguera, M. (2009). Insulte usted sabiendo lo que dice. En L. Luque Toro (ed.), Léxico español actual II (pp.31-48). Libreria Editrice Cafoscarina.

Bajtin, M. (1988). La cultura popular en la Edad Media y en el Renacimiento. Alianza Editorial.

Boissier de Sauvages, F. (1771). Nosologie methodique (Vol. II). Chez Hérissant.

Celdrán Gomáriz, P. (1995). Inventario general de insultos. Ediciones del Prado.

Celdrán Gomáriz, P. (2008). El gran libro de los insultos. La Esfera de los Libros.

Cipolla, C. (1996). Las leyes fundamentales de la estupidez humana. Cuadernos de economía, 15 (25), 200-216. https://revistas.unal.edu.co/index.php/ceconomia/article/view/13270

Colín Rodea, M. (2005). Modelo interpretativo para el estudio del insulto. Estudios de Lingüística Aplicada, 41, 13-37. https://ela.enallt.unam.mx/index.php/ela /article/view/467

Colín Rodea, M. (2007). El insulto: un fenómeno pragmático de base semántica. Lingüística mexicana, 4 (1), 51-72. http://amla.org.mx/linguistica_mexicana/Vol_IV/2007040103a.pdf

Corominas, J. (1987). Breve diccionario de la lengua castellana (3a ed.). Gredos.

De Covarrubias, S. (1611). Tesoro de la lengua castellana. Luis Sánchez, impresor del Rey.

De Olivé, P. M. (1843). Diccionario de sinónimos de la lengua castellana (Vol. 2). Imprenta de I. Boix.

De Quevedo Villegas, F. Invectivas contra los necios. En Obras (Vol. 1, pp. 443-451). Imprenta de M. Rivadeneira.

De Valera, C. (1602). La Biblia. Casa de Lorenço Iacobi.

Descuret, J. B. F. (1857). La medicina de las pasiones. Imprenta y librería de Pablo Riera.

Erasmo de Rotterdam, D. (1842). Elogio de la locura. Imprenta de José Tauló.

Esquirol, J.-E. D. (1856). Tratado completo de las enagenaciones mentales, consideradas bajo su aspecto médico, higiénico y médico-legal. Librería de don León de Pablo Villaverde.

Feijoo y Montenegro, B. J. (1863). Obras escogidas. M. Rivadeneira.

Ferrater Mora, J. (1996). Variaciones sobre la tontería. En J. Gracia (ed.), El ensayo español (Vol. 5, pp. 122- 


\section{1). Crítica.}

Flaubert, G. (1978). Bouvard y Pécuchet. Bruguera.

Graeber, D. (2015). The Utopia of Rules: On Technology, Stupidity, and the Secret Joys of Bureaucracy. Melville House.

James, A. (2016). Trump: ensayo sobre la imbecilidad. Malpaso Ediciones.

Jiménez, M. (ed.). (1843). Diccionario de los diccionarios de medicina publicados en Europa. Imprenta médica. Kant, I. (2004). Antropología en sentido pragmático. Alianza Editorial.

Lisowska, M. (2011). 'La falta de inteligencia' como objeto de insulto. Un análisis sobre el léxico coloquial y argótico del español contemporáneo. Romanica Cracoviensia, 11, 258-266. https://www.ceeol. $\mathrm{com} / \mathrm{search} /$ article-detail?id $=89568$

Lisowska, M. (2012). Sobre el insulto y el léxico denigratorio. Neophilologica, 24, 167-176. https://www. ceeol.com/search/article-detail?id=153640

Mata, P. (1857). Tratado de medicina y cirugía legal teórica y práctica (Vol. 2). Carlos Bailly-Bailliere.

Musil, R. (2014). Über die Dummheit. Dearbooks.

Luque Durán, J. D., Pamies Bertrán, A., y Manjón Pozas, F. J. (1997). El arte del insulto: Estudio lexicográfico. Península.

Pinel, P. (1803). Nosografía filosófica. Imprenta Real.

Pinel, P. (1804). Tratado médico-filosófico de la enagenación del alma, o manía. Imprenta Real.

Real Academia Española. (1783). Diccionario de la lengua castellana. Joaquín Ibarra, Impresor de Cámara de S. M. y de la Real Academia.

Real Academia Española. (1783). Diccionario de la lengua castellana. Imprenta Real.

Real Academia Española. (2020a). Corpus diacrónico del español (CORDE). http://corpus.rae.es/cordenet.html

Real Academia Española. (2020b). Corpus de referencia del español actual (CREA). http://corpus.rae.es/ creanet.html

Real Academia Española. (2020c). Diccionario de la lengua española. https://dle.rae.es/

Richter, J.-P. (2012). Elogio de la estupidez. Sequitur.

San Isidoro de Sevilla. (2004). Etimologías. Biblioteca de Autores Cristianos.

Tabernero Sala, C. (2016). Anti-modelos sociales e insultos en la Navarra del Siglo de Oro: de bellacos a pícaros. En I. Arellano Ayuso (ed.), Modelos de vida y cultura en la Navarra de la modernidad temprana (pp. 251-280). Instituto de Estudios Auriseculares (IDEA).

Tabernero Sala, C. (2018). Indicadores sociolingüísticos y pragmáticos del insulto (siglos XVI y XVII). En M. L. Arnal Purroy, R. Castañer Martín, J. M. Enguita Utrilla, V. Lagüéns Gracia y M. A. Martín Zorraquino (eds.), Actas del X Congreso Internacional de Historia de la Lengua Española (Vol. 2, pp. 1459-1477). Institución Fernando el Católico.

Tabori, P. (1993). The Natural History of Stupidity. Barnes \& Noble. 

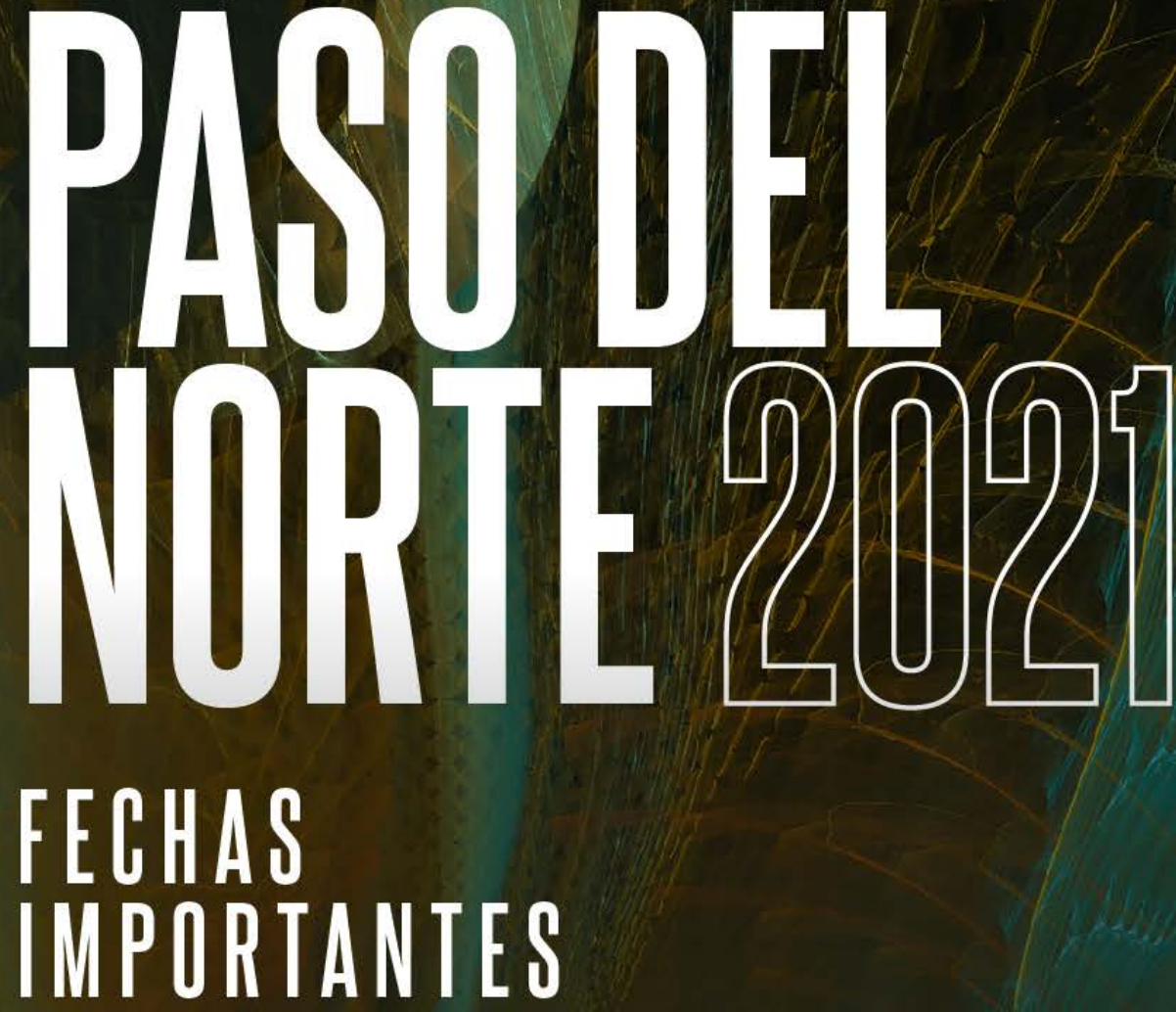

Recepción de trabajo

Del 15 de febrero al 7 de junio

Publicación de propuestas aceptadas 30 de julio

\begin{tabular}{ll}
\hline Fecha límite envío ponencias in extenso & $\mathbf{3 0}$ de septiembre \\
\hline Fecha límite de inscripción para ponentes & $\mathbf{8}$ de octubre \\
\hline Publicación del programa del Congreso & $\mathbf{2 2}$ de octubre \\
\hline Realización del Congreso & del $\mathbf{8}$ al $\mathbf{1 1}$ de noviembre \\
\hline Fecha límite para trámite de constancias & $\mathbf{3 0}$ de noviembre
\end{tabular}

Fecha límite para trámite de constancias

30 de noviembre

Registro de trabajos:

http://info.uacj.mx/congresocs2021 